\title{
Multikulturalizm: ewolucja dyskursu
} Multikulturalism: Evolution of Discours

Stowa kluczowe: multikulturalizm, imigracja, Unia Europejska, USA, dyskurs

Keywords: multiculturalism, immigration, European Union, USA, discourse

\begin{abstract}
Abstrakt: Ideologia multikulturalizmu to zespót przekonań o tym, że właściwym $w$ państwach Zachodu modelem społeczeństwa jest mozaika grup etnicznych, religijnych $i$ rasowych. Stużyć ma to wzrostowi gospodarczemu. Model ten unieważnia nacjonalizm - zarzewie konfliktów i wojen. Imigracja stuży takiej właśnie społecznej transformacji. Od połowy lat osiemdziesiatych XX $w$. ideologia ta wyznaczała ramy publicznej debaty oraz polityki względem imigracji. Dotychczasowy multikulturalny konsensus elit opinii, władzy $i$ pieniądza Zachodu zaczyna stabnać. Wcześniej marginalizowana krytyka coraz szerzej dochodzi do głosu.
\end{abstract}

Abstract: Multiculturalism as an ideology claims that Western societies ought to be transformed into patchworks of ethnicities, religions and races. It is supposed to help the economy grow. It also cancels out nationalism - the root cause of conflict and war. Immigration brings about such social transformation. From the mid-1980s that ideology set out the limits of public debate and underpinned immigration policies. However, the multicultural consensus of Western elites of opinion, power and money seems to be crumbling. Erstwhile marginalized, its critique becomes ever louder.

* ORCID ID: https://orcid.org/0000-0002-2528-3903, dr hab., Katedra Studiów Regionalnych i Globalnych Wydziału Nauk Politycznych i Studiów Międzynarodowych Uniwersytetu Warszawskiego. E-mail: j.ciechanski@uw.edu.pl 


\section{Wstęp}

W połowie lat osiemdziesiątych XX w. ukształtował się w państwach Zachodu konsensus elit opiniotwórczych w sprawie multikulturalizmu. Z faktu społecznego, multikulturalizm stał się ideologią wyznaczającą właściwy model społeczeństw państw Zachodu. Wkroczył więc do polityki. „Multikultutalizacja” tamtejszych społeczeństw miała być, z powodów demograficznych, nieuchronna, z powodów ekonomicznych - korzystna, z powodów etycznych natomiast - dobra. Multikulturalizm miał być więc przepisem na gospodarczy sukces w globalizującym się świecie, a nawet na pokojowe współistnienie w stosunkach międzynarodowych. Przede wszystkim zaś, stanowił ekspiację zachodnich społeczeństw za ich kolonizatorską, rasistowską i niewolniczą przeszłość, a przez to antidotum na obecny w nich rasizm, nacjonalizm, szowinizm. Z tych powodów odrzucono dotychczasowy wymóg asymilacji imigrantów w zachodnich krajach ich osiedlenia. Asymilując się, pozaeuropejscy imigranci nie tylko podlegaliby powtórnej wiktymizacji kulturowego tym razem imperializmu, ale nie mogliby „ubogacać” swoją kulturą rodzimą kultury państwa osiedlenia, która wymagała wszak „dekonstrukcji” i „rekonstrukcji” wedle ideologicznego kanonu. Mozaika kultur, religii i ras miała oczyszczać kulturę Zachodu z jej przemocowej istoty, obiecując prawdziwą społeczną harmonię. Filozoficzną podstawę multikulturalizmu jako ideologii oraz praktyki politycznej stanowił postmodernizm. Wszak to w jego kontrkulturowych oparach kształciły się od rewolty roku 1968 społeczne elity które dwie, trzy dekady później objęły władzę. Chodzi więc o gramsciańskie pojmowanie ideologii, nie jako formy „fałszywej świadomości”, lecz inspiracji do „postępowej” transformacji społeczeństwa, tj. rozmontowania przez kontrkulturę tego, co w tradycyjnej kulturze ideologia uznaje za opresyjne ${ }^{1}$.

W dobie postmodernizmu, sowa Minerwy nie rozpościera już swych skrzydeł o zmierzchu. Wiedzę nowoczesną, ustrukturyzowaną i ugruntowaną, kumulowaną w czasie oraz uniwersalną Jacques Derrida zredukował do „mitologii białych”, tj. do jednej z możliwych narracji ${ }^{2}$. A skoro język jest bezradny w opisie rzeczywistości, bo „znaczące” i znaczone” (signifier and signified) pozostają zawsze w luźnym związku, kluczowe stają

1 E. Ari, Ideology of Multiculturalism as a Double-Edged Sword: Second-Generation of Black Jamaicans and Dark-White Portuguese, s. 14-15, https://ir.lib.uwo.ca/etd/5353 (12.10.2020).

2 J. Derrida, White Mythology: Metaphor in the Text of Philosophy, [w:] J. Derrida, Margins of Philosophy, Chicago 1984, s. 208-271. 
się interpretacje ${ }^{3}$. W dyskursie, „mitologia białych” może być tylko jedną z nich; trzeba doprosić mitologie innych, wykluczonych dotąd poza margines filozofii. Dyskurs nabierze wówczas pełni znaczeń. Przede wszystkim zaś pozwoli tę panującą dotąd mitologię-narrację zdekonstruować w kierunku afirmacji multikulturalizmu.

Przypieczętowanie moralnej słuszności multikulturalizmu wymagało marginalizacji oponentów, których ideologia ta obsadzała w rolach bigotów, rasistów, natywistów itp. Było to skuteczne w Ameryce Martina Luthera Kinga, czy w „przepracowującej” swój kolonializm oraz antysemityzm zachodniej Europie. W końcu jednak do wystarczająco wielu zaczęło docierać, że aby te grzechy odkupić, trzeba pogodzić się z jeszcze jedną rolą: obcego we własnym kraju. Cena odkupienia okazała się absurdalna. Przy czym, nie chodzi tu tylko o spór na poziomie etycznym. Realizacja wyśnionej przez Derridę i innych utopii zagroziła rozpadem narodowej wspólnoty ze wszystkimi tego społecznymi i gospodarczymi konsekwencjami. I tak - ku zaskoczeniu samych multukulturalistów - coraz śmielej i częściej zaczęły rozlegać się głosy kwestionujące narzucone przez nich dogmaty. Do status quo ante powrotu już nie ma. Ani w sensie struktury etnicznej społeczeństw państw rozwiniętych, ani polityki twardej asymilacji imigrantów. Narasta jednak opór wobec dotychczasowej dominacji multikulturalizmu jako ideologii politycznej oraz wobec przepisanego przez nią modelu społeczeństwa. Oto ewolucja dyskursu w tej kwestii.

\section{Ideowe oraz polityczno-gospodarcze podłoże multikulturalizmu: progresywne elity, polityczna lewica i biznes}

Największym paradoksem dzisiejszych problemów demokratycznych społeczeństw Zachodu, z masową imigracją spoza zachodniego kręgu kulturowego i przekształceniem społeczeństw tych krajów w społeczeństwa wielokulturowe, jest to, że odbyło się to bez jakiejkolwiek publicznej debaty. Elity władzy i opinii nigdy nie zapytały społeczeństw czy takiej transformacji własnych krajów sobie życzą. Pierwszą wielką falę powojennej imigracji do Niemiec lat 1955-1965 nazywano „gastarbeiterami”, tj. „pracownikami-gośćmi”, a goście nie pozostają przecież w gościnie na stałe. Zaś przyjmowanie „nieproszonych gości” w postaci mas nielegalnych imigrantów, było wówczas w ogóle nie do pomyślenia. Wprowa-

3 J. Derrida, Structure, Sign and Play in the Discourse of Human Sciences, http://www2.csudh. edu/ccauthen/576f13/DrrdaSSP.pdf (8.10.2020). 
dzając w 1965 r. reformę imigracyjną w Stanach Zjednoczonych, która odrzuciła uprzywilejowujące imigrantów z Europy kwoty geograficzne, demokratyczny prezydent Lyndon B. Johnson uspokajał Amerykanów, że „nie chodzi o żadną rewolucję”. Zapewniał, że nowa regulacja „nie wpłynie na życie milionów” obywateli. Jak się miało okazać, oparcie preferencji imigracyjnych na zasadzie łączenia rodzin doprowadziło do jak najbardziej rewolucyjnego przeobrażenia demograficznego oblicza Ameryki ${ }^{4}$. O ile w przypadku gastarbeiterów można mówić o zaskoczeniu, o tyle w przypadku amerykańskim, mimo zaprzeczeń - o premedytacji, ponieważ to, że rodziny latynoskie są znacznie liczniejsze od europejskich, już wtedy było oczywiste ${ }^{5}$.

Krytycy tego wielkiego eksperymentu społecznego, jakiego dokonano na społeczeństwach wielu państw zachodnich wskazują, że było to możliwe w wyniku zbiegu dążeń i interesów progresywnych elit, politycznej lewicy oraz biznesu ${ }^{6}$. Progresywne elity opinii chciały wyzwolenia społeczeństwa z opresji tradycji. Wydziały humanistyczne uniwersytetów, media oraz partie polityczne głównego nurtu opanowane zostały na Zachodzie Europy oraz w Stanach Zjednoczonych i Kanadzie, przez pokolenie rewolty studenckiej roku 1968, z dominującą w jego opiniotwórczej części filozofią postmodernizmu i wynikającą z niej afirmacją multikulturalizmu. Postmodernizm postrzega wszystkie relacje społeczne jako relacje władcze, które należy „zdekonstruować”7. Oczywistym instrumentem „opresji” wobec innych jest też zachodnia kultura, która powinna zostać zdekonstruowana i w efekcie, potępiona. Tak to semiologiczne elukubracje Derridy nabrały praktycznego znaczenia. Z niezwykłą dla samego Derridy - lecz w rzeczowej Ameryce niezbędną - semiotyczną precyzją, jeden z jego tamtejszych wyznawców tak oto sprowadza je do interesującego nas tu politycznego konkretu:

4 U.S. Postwar Immigration Policy: 1952-2019, Council on Foreign Relations Timeline, 2020, https://www.cfr.org/timeline/us-postwar-immigration-policy (12.10.2020).

5 The Legacy of the 1965 Immigration Act: Three Decades of Mass Immigration, Center for Immigration Studies, September 1, 1995, https://cis.org/Report/Legacy-1965-Immigration-Act (12.10.2020); T. Gjelten, The Immigration Act That Inadvertently Changed America, «The Atlantic», 2.10.2015, https://www.theatlantic.com/politics/archive/2015/10/immigration-act-1965/408409/ (12.10.2020).

6 M. Bock-Côté, Le multiculturalisme comme religion politique, Paris 2016, wyd. pol.: Multikulturalizm jako religia polityczna, Warszawa 2017.

7 S. Hicks, Explaining Postmodernism: Skepticism and Socialism from Rousseau to Foucault, b.m.publ. 2011, s. 1-20. 
Istotą dekonstrukcji jest zdekonstruowanie mechanizmu potężnych państw narodowych prowadzących zdecydowaną politykę imigracyjną, zdekonstruowanie retoryki nacjonalizmu, polityki terytorium, metafizyki ojczyzny i ojczystego języka ..., jest nią rozbrajanie bomb ... [odrębnych] tożsamości - wytworu państw narodowych służącego obronie przed obcym, przed Żydami, przed Arabami i [w ogóle przed] imigrantami. ... [T] a dekonstrukcyjna pasja jest głęboko polityczna, jako że dekonstrukcja jest nieustępliwym, choć czasem wymijającym, dyskursem o ... demokracji przyszłości ${ }^{8}$.

W demokracji wyśnionej przez Derridę nie ma już miejsca na narodową czy etniczną tożsamość, nie ma miejsca na jakąkolwiek tożsamość albo wspólnotę, gdyż te - pielęgnując to co wspólne - wykluczają innego ${ }^{9}$.

Lewicowi politycy w zmianie składu etnicznego swych społeczeństw upatrywali źródeł głosów, które miały zapewnić im udział we władzy. Dotychczasowa klientela - robotnicy nie chcieli już na nich głosować tak masowo, jak dawniej. Wraz ze wzrostem zamożności pracownicy najemni stawali się konserwatywni. Dlatego, chcąc zdobywać głosy, lewica skupiła się na „polityce tożsamości” („identity politics”), tj. na obronie różnych mniejszości, rzekomo prześladowanych przez z definicji „opresyjną" większość. Forsowano przy tym kod politycznej poprawności, co uniemożliwiało debatę ${ }^{10}$. Instrumentem multikulturalnej transformacji społeczeństw stały się prawa człowieka oraz realizujące je instytucje ich ochrony (rzecznicy, sądy), które do działania nie potrzebują demokratycznej legitymacji. Dlatego, poza demokratyczną kontrolą, mogły kreować wciąż nowe „prawa” chroniące wciąż nowe grupy podlegające „opresji” i „dyskryminacji” przez większość.

Z kolei, biznes chciał i chce taniej siły roboczej. Skrzętnie prywatyzuje zyski wynikające $\mathrm{z}$ niskich płac, niewykształconych i niewykwalifikowanych imigrantów ${ }^{11}$, pozostawiając integrację społeczną ich i ich licznych rodzin zmartwieniu władz publicznych, czyli uspołeczniając rosnące koszty imigracji. Standardowe „oczywiste” wyjaśnienie jest takie, że imigranci wykonują zajęcia, których nie chcą wykonywać obywatele bogatych państw zachodnich. Pomija się natomiast w tej argumentacji, że chodzi o prace najniżej opłacane. Gdyby zacząć płacić za nie więcej, okazać by

8 J. Caputo, The Prayers and Tears of Jacques Derrida: Religion Without Religion, Bloomington 1997, s. 231.

9 Tamże, s. 231.

10 S. Hicks, Explaining..., s. 135-173, 224-239; M. Lilla, The Shipwrecked Mind: On Political Reaction, New York 2016, s. 114.

11 Eurostat, http://ec.europa.eu/eurostat/statistics-explained/index.php/Migrant_integration_statistics_-_education (12.10.2020). 
się mogło, że rodzimi Amerykanie czy Europejczycy zaczną się do tych prac garnąć. Poza tym, gdyby prawdą była inna biznesowa „oczywistość”, że starzejąca się UE potrzebuje rąk do pracy, to nie byłoby w Europie bezrobocia. A jest i UE oraz jej państwa członkowskie wymyślają wciąż nowe strategie jego zwalczania ${ }^{12}$.

Nie chodzi tu bynajmniej o jakiś spisek elit. Postmodernizm dał ideologii multikulturalizmu filozoficzne podstawy, interes polityczny lewicowo-liberalnych elit zapewnił jej dominację w przestrzeni publicznej, wspieraną dodatkowo ekonomicznym interesem elit biznesu. Droga do „nowego wspaniałego świata” stanęła otworem. Każde państwo podążyło nią w nieco odmienny sposób, ale efekt był wszędzie podobnie problematyczny: „społeczeństwa są podzielone, mniejszości - wyobcowane, zaś obywatele - oburzeni ${ }^{13}$.

Marsz multukulturalizmu przez państwa Zachodu długo nie napotykał społecznego oporu. Zmiany struktury demograficznej społeczeństw były powolne, korzyści ekonomiczne zaś - doraźne. Imigranci długo pozostawali tė̇ „niewidoczni”, gdyż ich rosnące masy polityczna praktyka spychała na społeczne oraz geograficzne peryferia. Obserwowany od początku XXI w. stopniowy odwrót wyborców od partii lewicowych i centrolewicowych na Zachodzie tłumaczono deindustrializacją, koniecznością dostosowania do możliwości finansowych rozbudowanego wcześniej nadmiernie „państwa opiekuńczego” oraz populizmem, który miał być zjawiskiem przejściowym ${ }^{14}$. Narastający problem niezintegrowanych kulturowo milionowych społeczności imigranckich w Europie oraz nielegalnych, głównie latynoskich, imigrantów w Stanach Zjednoczonych pomijano lub wręcz rugowano z debaty publicznej oskarżeniami krytyków o rasizm. Istotną rolę odgrywały w tym media głównego nurtu, które przestały odgrywać rolę agory, stając się - również w kwestii imigracji - tubą politycznej poprawności. Utraciły w ten sposób społeczną wiarygodność, a dyskusja przeniosła się do mediów społecznościowych,

12 A. Lubowski, Europa przechodzi na islam, «Gazeta Wyborcza» 2-3.01.2010, s. 10-11.

13 K. Malik, The Failure of Multiculturalism: Community Versus Society in Europe, «Foreign Affairs» 2015, vol. 94, nr 2, s. 21; M. Ruthven, How Europe lost faith in multiculturalism, «Financial Times» 24.08.2017, https://www.ft.com/content/dd122a8c-8720-11e7-8bb15ba57d47eff7 (12.10.2020).

14 C. Bickerton, The collapse of Europe's mainstream left, «New Statesman» 1.05.2018, https://www.newstatesman.com/world/europe/2018/05/collapse-europe-s-mainstreamcentre-left (12.10.2020). 
utkwiwszy tam w ideologicznych bańkach ${ }^{15}$. Stopniowo rosnąć zaczęła popularność ugrupowań i ruchów antyestablishmentowych. Najpierw we Francji, w Niemczech, Stanach Zjednoczonych, Hiszpanii, Grecji, Holandii, Włoszech, Wielkiej Brytanii oraz w państwach nordyckich. Dopiero później - na Węgrzech, w Polsce, Czzechach i na Słowacji ${ }^{16}$. Oblicze ideowe tych ruchów jest - jak się wydaje - głównie anty-kontrkulturowe, zaś antyimigranckie tylko w tym sensie, że odrzucające oficjalnie propagowaną politykę „tożsamości grupowych” („identity politics”). Kryzys finansowy i gospodarczy Zachodu lat 2007-2011, a następnie kryzys imigracyjny UE roku 2015 były katalizatorami, zaś Brexit (w którym antyimigrancki resentyment miał istotne znaczenie) oraz wybór Donalda Trumpa na prezydenta Stanów Zjednoczonych w roku 2016 - paroksyzmami anty-kontrkulturowego „buntu mas”, który narastał od lat. Zachwiał on dotychczasowym multikulturalnym konsensusem elit akademii, polityki i pieniądza. Żeby bunt ów nie stał się tylko prostacką reakcją „umysłu rozbitego” („shipwrecked mind”) na wypaczenia kontrkulturowej rewolucji zależeć będzie od tego, czy możliwy jest nowy konsensus elit - jakaś nowa synteza uwzględniająca fakt, że zarówno powrót do „raju utraconego”, jak i kroczenie dotychczasową drogą prowadziłyby do katastrofy ${ }^{17}$.

\section{Erozja konsensusu elit wobec ideologii multikulturalizmu}

Krytykę kulturalnego relatywizmu propagowanego na uniwersyteckich wydziałach humanistycznych, z czego później wyrósł polityczny multikulturalizm, już w 1987 r. podjął Allan Bloom książką o „umyśle zamkniętym”18. Bestseller A. Blooma wywołał dyskusję, ale nie przeorał opinii. W odniesieniu do imigracji, erozja politycznego konsensusu rozpoczęła się dopiero wraz zakończeniem „zimnej wojny”. Islamski fundamentalizm i związany z nim polityczny terroryzm ujawnił się jako nowy

15 Zob. np. T. Koppel, Truth be Told: Journalism in the Age of Trump, «The Kalb Report», Washington, D.C. 2018, https://www.youtube.com/watch?v=DzQZsudzLao (12.10.2020).

16 K. Malik, The Failure..., s. 24, 28, 30-31; A. Nardelli, G. Arnett, Why are anti-immigration parties so strong in the Nordic states?, «The Guardian» 19.06.2015, https://www. theguardian.com/news/datablog/2015/jun/19/rightwing-anti-immigration-parties-nordic-countries-denmark-sweden-finland-norway (10.10.2020).

17 M. Lilla, The Shipwrecked..., s. ix-xv.

18 A. Bloom, The Closing of the American Mind: How Higher Education Has Failed Democracy And Impoverished the Souls of Today's Students, New York 1987. 
wróg Zachodu. Jednocześnie, świat wszedł w erę globalizacji. Jednym z jej skutków była narastająca ghettoizacja zachodnich społeczeństw (szczególnie dużych miast), do których ściaggały rzesze światowej biedoty w poszukiwaniu lepszego życia. Multikulturalny dogmat nie pozwalał na jej kulturową integrację. Musiało to w końcu zrodzić społeczne napięcia. Rzeczywistość imigranckich ghett z ich roszczeniami, alienacją i patologiami coraz bardziej odstawała od progresywnej wizji „nowego wspaniałego świata” multikulturalnej harmonii ${ }^{19}$.

W Polsce, na zmianę podejścia do imigracji bodaj pierwsza zwróciła uwagę Dominika Kozłowska, redaktor naczelna miesięcznika ZNAK, podczas debaty Fundacji Batorego, w październiku 2017 r. Zauważyła ona, że zmiana ta zaszła niejako równolegle w Stanach Zjednoczonych i w Europie. Po „zimnej wojnie” dotychczasowy podział ideologiczny zastąpiony został podziałem cywilizacyjnym: „z jednej strony na świat judeochrześcijański, z drugiej strony świat islamu: wizje dwóch, nie dających się uzgodnić tożsamości”. Wskazywała na znaczenie książki Samuela Huntingtona o zderzeniu cywilizacji z 1993 r., zaś w Europie - książki Oriany Fallaci, Wściekłość i duma z 2001 r., reakcji sławnej dziennikarki na zamach na World Trade Center ${ }^{20}$. D. Kozłowska zauważała, że w odniesieniu do przyjmowania pozaeuropejskich imigrantów, następuje w polityce państw europejskich stopniowe przesunięcie od multikulturalizmu w kierunku oczekiwania kulturowej integracji. Coraz wyraźniej widać, że przesunięcie to ma charakter niejako ekumeniczny: jego potrzebę dostrzegają już nie tylko konserwatyści, lecz coraz częściej, także liberałowie oraz przedstawiciele lewicy. Motywy konserwatystów mogą być ideowe, zaś liberałów czy lewicy - pragmatyczne, ale konsensus wokół potrzeby odrzucenia dotychczasowej multikulturalnej ortodoksji wydaje się coraz bardziej umacniać.

W 1989 r. Francis Fukuyama opublikował sławny esej o „końcu historii”. Prorokuje w nim zwycięstwo liberalnej demokracji oraz koniec ideologii, w tym nacjonalizmu oraz teokracji, ze względu na ich wykluczający charakter ${ }^{21}$. Rozeźliło to Samuela Huntingtona, skądinąd profesora F. Fukuyamy z Harvardu, który odpowiedział mu w 1993 r. esejem o konflikcie cywilizacji - nowym fundamentalnym sporze definiującym

19 Kwestię niekompatybilności wartości cywilizacji islamskiej i zachodniej w debacie publicznej ujawniła na przełomie lat 80. i 90. XX w. powieść S. Rushiego Szatańskie wersety (Satanic Verses), która ukazała się w 1988 r.

20 Stosunek do Europy: rola Polski i polskiego Kościoła, Debata Fundacji Batorego, 24.10.2017, https://www.youtube.com/watch? $=$ WKm00dOI_ns\&t $=48 \mathrm{~s}$ (12.10.2020).

21 F. Fukuyama, The End of History?, «The National Interest» Summer 1989, nr 16, s. 3-18. 
post-zimnowojenny świat. Ze względu na swą potęgę, dobrobyt oraz uniwersalistyczne pretensje liberalnej demokracji, Zachód znajdzie się w centrum tego konfliktu, zaś do najostrzejszego starcia dojdzie z cywilizacją islamu 22 . Atak na World Trade Center, 9 września 2001 r. zdawał się potwierdzać diagnozy S. Huntingtona. Krótko potem, w 2004 r., S. Huntington opublikował książkę pytającą Amerykę o jej tożsamość. Podejmuje w niej problem nadmiernej imigracji odrębnej kulturowo ludności latynoskiej do Stanów Zjednoczonych. Stawia tezę, że sukces Ameryki wynika z jej anglosaskich wartości. Tę kulturę ukształtowali osadnicy (settlers), którzy przybyli na amerykański kontynent, a nie imigranci, którzy przybyli do stworzonego już na nim przez osadników państwa. To rozróżnienie jest ważne, ponieważ hierarchizuje kulturowo kulturę osadników i kulturę imigrantów. A że każda kultura ma ograniczone możliwości asymilacji przybyszy z innych kultur, nadmierna imigracja latynoska stanowi więc zagrożenie dla spójności kulturowej narodu amerykańskiego, w związku z tym dla zestawu anglo-protestanckich wartości, który zdecydował o sukcesie Ameryki23.

Myśl O. Fallaci podążała podobnymi ścieżkami, choć wyrażona została o wiele dobitniej. Wściekłość $i$ duma była wszak reakcją na terrorystyczny atak na World Trade Center oraz na „zrozumienie”, z jakim w niektórych grupach społecznych spotkali się sprawcy i ich obrzydliwy czyn. O. Fallaci, której polityczne przekonania nigdy nie mieściły się w tradycyjnych podziałach lewica-prawica, na strzępy rozerwała kokon politycznej poprawności otulający dotąd szczelnie kwestię masowej muzułmańskiej imigracji do krajów Zachodu. Z właściwą sobie pasją ogłosiła klęskę europejskiej polityki wielokulturowości. Oskarżyła elity kultury, polityki i mediów, które - dla ich bezmyślnego reprodukowania wciąż tych samych dźwięków - nazwała „cykadami”, o bagatelizowanie bądź przemilczanie muzułmańskiego rasizmu, antyzachodniej pogardy przywódców i aktywistów muzułmańskich społeczności w Europie oraz nawoływań niektórych z nich do mordowania „niewiernych”, jak również o tolerowanie w tych społecznościach praktyk sprzecznych z wartościami europejskimi, jak dyskryminowanie kobiet, okaleczanie narządów płciowych dziewczynek, współżycie z nieletnimi oraz aranżowanie z nimi małżeństw. Przemilcza się też albo bagatelizuje religijnie motywowany terroryzm. Sprzyjaniu islamowi szczególnie przez lewicowo-liberalne europejskie elity towarzyszy odrzucenie przez nie chrześcijaństwa postrzeganego jako opresyjne

22 S. Huntington, The Clash of Civilizations?, «Foreign Affairs» 1994, vol. 72, nr 3, s. 22-49.

23 S. Huntington, Who Are We? America's Great Debate, London 2004, szczególnie s. 37-80. 
oraz patriotyzmu postrzeganego jako groźny nacjonalizm. O. Fallaci uznała muzułmanów za grupę nienadającą się do asymilacji w Europie, zaś wiarę w upowszechnienie się „umiarkowanego” islamu za mrzonkę. Chyba największą wściekłość krewkiej Włoszki wzbudziły te politycznie poprawne elitarne „cykady”, czy wręcz „putains à la page”, tj. „dziwki słowa”, które otumaniają współobywateli powiastkami o równowartościowości kultur. Oto próbka jej krytyki ówczesnego premiera Wielkiej Brytanii Tony'ego Blaira:

[J]eśli twierdzi pan, że nasza cywilizacja jest równa tej, która narzuca czador i burkę, to nie jest pan lepszy niż włoskie cykady. Jeśli nie broni pan naszej kultury, mojej kultury i pana kultury, mojego Leonarda da Vinci i pańskiego Szekspira, jeśli nie potrafi pan o to walczyć, to jest pan także cykadą, a ja pytam: dlaczego wybiera pan moją Toskanię, moją Florencję, moją Sienę, moją Pizę, moje Uffizi, moje Morze Tyrreńskie na wakacje? Dlaczego nie pojedzie pan do Rijadu, Kabulu, na pustynie Arabii Saudyjskiej czy do skalistego ponurego Afganistanu?24

Charakterystyczne było to, że recepcja eseju oraz książki S. Huntingtona często polegała na atakach ad personam, zarzucających autorowi recykling starych argumentów, subiektywizm, nadmierne generalizacje, etc. Jeden z krytyków nazwał pracę Huntingtona „zrzędliwą, przerysowaną, niezwykle kontrowersyjną ... opryszczoną zdumiewającymi sprzecznościami oraz zastanawiającymi obserwacjami kogoś mającego klapki na oczach" 25. Z jeszcze ostrzejszymi atakami spotkała się Wściektość i duma. O. Fallaci oskarżono o rasizm oraz o to, że jest plagiatorką A. Hitlera. Mimo to, na ideach S. Huntingtona oraz O. Fallaci zogniskowała się wówczas debata publiczna. Zaczęły one nadawać intelektualny kształt odczuciom zwykłych Amerykanów oraz Europejczyków - tych wszystkich, których później Hillary Clinton miała nazwać „godnymi pogardy” (deplorables $)^{26}$.

24 O. Fallaci, La rabbia e l'Orgoglio, Milano 2001, wyd. pol. Wściektość i duma, Warszawa 2003, s. 166 (odniesienie do „putains à la page”, s. 174).

25 M. Kakutani, Books of the Times; An Identity Crisis for Norman Rockwell America, «The New York Times» 24.05.2004, https://www.nytimes.com/2004/05/28/books/books-ofthe-times-an-identity-crisis-for-norman-rockwell-america.html (12.10.2020); S. Huntington: US political scientist who foresaw future conflict arising from a clash of cultures, «The Guardian»1.012009, https://www.theguardian.com/world/2009/jan/01/obituarysamuel-huntington (12.10.2020).

26 H. Clinton, Remarks from the LGBT for Hillary gala, «Time» 19.09.2016, http://time. com/4486502/hillary-clinton-basket-of-deplorables-transcript/ (12.10.2020). 
Zauważano też niekorzystne dla Zachodu, szczególnie zaś Europy, trendy demograficzne. Konserwatywny amerykański historyk Walter Laqueur w książce z 2009 r. o ostatnich dniach Europy zauważał, że do 2060 r. liczba ludności EU-27 zmniejszy się z 495,4 miliona w 2008 r. do 416,5 miliona, tj. o prawie 79 milionów. Do 2050 r. liczba ludności Europy spadnie nie tylko absolutnie, ale także w proporcji do liczby ludności reszty świata. Udział ludności Europy w ludności świata, który w 1900 r. wynosił 25\%, w 1950 r. - 12\%, w 2050 r. sięgnie 4-5\%. Europa znajdzie się wówczas w towarzystwie 100-milionowej Turcji, 114-milionowego Egiptu, oraz Algierii i Maroka, które będą liczyły po 45 milionów ludzi ${ }^{27}$. W. Laqueur przestrzegał przed nadmierną koncentracją imigrantów z krajów muzułmańskich w miastach. Już w 2009 r. (kiedy książka się ukazała), imigracja z Turcji, Afryki Północnej i Bliskiego Wschodu koncentrowała się w dużych europejskich miastach i szybko przyrastała, np. we Francji z 2,5 mln w 1980 r. do 5,5 mln w 2006 r. W Holandii w tym samym okresie liczba ludności muzułmańskiej zwiększyła się z 0,5 mln do $1 \mathrm{mln}$. We Włoszech i w Hiszpanii - ze 120 tys. w 1982 r. do ok. 1 mln w 2006 r. itd. Widoczne były też już wówczas skutki tego, że społeczności muzułmańskie są istotnie młodsze od pozostałych, gdyż charakteryzują się wyższym wskaźnikiem dzietności, np. w Brukseli udział ludności muzułmańskiej wynosił tylko 15\%, ale już 25\% w grupie poniżej 25. roku życia. W rodzinach imigranckich rodziło się 55\% dzieci. Bruksela nie jest odosobnionym przypadkiem. Odnośne wskaźniki są nawet wyższe w wielu miastach Holandii. Przewidywano, że już w 2015 r. udział obcokrajowców, głównie muzułmanów, w ludności Kolonii, Düsseldorfu, Wuppertalu, Duisburga i jeszcze wielu innych miast zachodnioniemieckich będzie ponad czterdziestoprocentowy. Inną cechą tych grup imigranckich jest to, że trudno integrują się w krajach zamieszkania, tworząc w nich zachowujące kulturową i językową odrębność alternatywne społeczeństwa $^{28}$. W 2009 r. W. Laqueur opisywał więc polityczną bombę zegarową, której istnienie wówczas najczęściej ignorowano.

W 2010 r., pod wrażeniem kryzysu gospodarczego, lewicowy historyk brytyjski, Tony Judt (zm. w tymże roku) opublikował książkę-polityczny testament pt. Źle ma sie kraj: rozprawa o naszych politycznych bolaczkach. Ubolewał w niej nad upadkiem „keynesowskiego konsensusu” na rzecz

27 Meeting Social Needs in a Ageing Society, 2nd European Demography Report 2008, European Commission, Commission Staff Working Document, Table 1.16, s. 54; W. Laqueur, The Last Days of Europe: Epitaph for an Old Continent, New York 2007, s. 26-27.

28 W. Laqueur, The Last Days..., s. 40-49. 
„waszyngtońskiego konsensusu”29. Częściowo obwiniał za to „wcześniejszą arogancję lewicy”: „To my przypisywaliśmy sobie wiedzę o tym jak należy zbawić świat. Ów fałszywy ton nieuzasadnionej arogancji odpowiada częściowo za [dzisiejszy] reakcyjny odwet" 30 . I dalej wyjaśniał, że wszystkie wspólnotowe przedsięwzięcia, a takim jest „państwo dobrobytu”, wymagają wzajemnego zaufania. A o nie najłatwiej w społeczeństwach niezbyt liczebnych oraz homogenicznych ${ }^{31}$. Z badań niewątpliwie wynika, że zróżnicowanie ekonomiczne i kulturowe podkopuje wzajemne zaufanie, konieczne dla funkcjonowania „państwa opiekuńczego”. „Stały wzrost liczby imigrantów, szczególnie imigrantów z 'trzeciego świata' wyraźnie koreluje ... z zasadniczym osłabieniem spójności społecznej. Mówiąc wprost, Holendrzy i Anglicy nie mają zamiaru dzielić się swym dobrobytem ze swymi byłymi kolonialnym poddanymi z Indonezji, Surinamu, Pakistanu czy Ugandy, zaś Duńczycy, podobnie jak Austriacy, oburzają się, kiedy każe im się 'płacić na’ muzułmańskich uchodźców, którzy zalewają ich kraje w ostatnich latach”32. Tym samym, lewicowy T. Judt zgodził się nie tylko z cytowanym wyżej konserwatywnym W. Laqueurem, ale też z wybitnym przedstawicielem „szkoły chicagowskiej” neoliberałem Miltonem Friedmanem, który dekadę wcześniej stwierdził na łamach The Wall Street Journal: „Jest oczywiste, że nie można mieć swobody imigracji i państwa dobrobytu”33. Książka T. Judt'a wywołała pewną konsternację elit, ale szybko zbyto ją jako napisaną tuż przed śmiercią, kiedy - w domyśle - autor nie był już sobą.

W 2010 r. politycznym wydarzeniem stała się w Niemczech książka ekonomisty, zasłużonego polityka SPD i członka zarządu Bundesbanku Thilo Sarazzina o samolikwidacji Niemiec. Wedle autora, ma ona być skutkiem dopuszczenia do osiedlenia się w Niemczech wielkiej liczby imigrantów muzułmańskich, którzy wskaźnikami dzietności znacznie wyprzedzają rodowitą ludność, tworząc jednocześnie nieasymilujące się w kulturze niemieckiej równoległe społeczeństwo ${ }^{34}$. Co więcej, imigranci ci nie chcą się integrować w niemieckiej kulturze i są gorzej wykształ-

29 T. Judt, Ill Fares the Land, New York 2010.

30 Tamże, s. 4.

31 Tamże, s. 67.

32 Tamże, s. 70.

33 R. Rector, Look to Milton: Open borders and the welfare state, The Heritage Foundation, 21.06.2007, https://www.heritage.org/immigration/commentary/look-milton-open-borders-and-the-welfare-state (12.10.2020).

34 T. Sarrazin, Deutschland schafft sich ab: Wie wir unser Land aufs Spiel setzen, München 2010. 
ceni niż ludność rodzima. Bardziej też niż ludność rodzima korzystają ze świadczeń socjalnych. Zastąpienie ludności rodzimej przez muzułmańską doprowadzi do upadku niemieckiego dobrobytu, który wynika z charakterystycznych dla Niemców wartości. Każde kolejne młode pokolenie jest w Niemczech o 35\% mniej liczne od poprzedniego. Będzie to miało katastrofalne skutki dla Niemiec - spowoduje ich samolikwidację. Sarazzin krytykował liberalne elity nie tylko za kneblowanie polityczną poprawnością rzeczowej dyskusji na ten kluczowy temat, ale też za to, że są one wobec problemu samolikwidacji Niemiec kompletnie obojętne.

Zamiast rzeczowej debaty, T. Sarazzina spotkał politycznie poprawny ostracyzm. Usunięto go z SPD, czego on sam nie uznał. Zmuszono go do ustąpienia ze stanowiska. Ale jego książka stała się w Niemczech bestsellerem. T. Sarrazin definiuje się konsekwentnie jako socjaldemokrata. Pytany o to wielokrotnie $\mathrm{w}$ wywiadach, podkreślał swoją wiarę w interwencjonizm państwowy oraz jego redystrybucyjną rolę, zapobiegającą nadmiernym różnicom dochodowym. $Z$ podobną popularnością u czytelników, a jednocześnie z ostracyzmem elit, spotkała się retorycznie o wiele bardziej agresywna, cztery lata późniejsza książka Érica Zemmoura, dziennikarza konserwatywnego Le Figaro, o imigracyjnym samobójstwie Francji. É. Zemmoura - Francuza o korzeniach żydowsko-algierskich, oskarżano m.in. o rasizm i antysemityzm ${ }^{35}$. Znamienne jest też, że książka T. Sarazzina ukazała się już po francusku, lecz nie po angielsku.

Kwestię alienacji elit podjął też Michel Houellebecq w powieści Uległośćc $^{36}$. Ukazała się ona we Francji w sprzedaży 7 stycznia 2015 r., w tym samym dniu, w którym dwaj urodzeni w Paryżu arabscy islamiści dokonali zamachu na satyryczny tygodnik Charlie Hebdo w odwecie za opublikowanie karykatur proroka Mahometa, mordując dwanaście osób oraz raniąc jedenaście. Wkrótce potem, doszło w regionie Paryża do podobnych aktów terroryzmu, skierowanych przeciwko Żydom; zabito cztery osoby. Powieść M. Houellebecqa zogniskowała, nie tylko we Francji, dyskusję wokół odpowiedzialności elit polityki i opinii za powstanie alternatywnego społeczeństwa, którego wartości nie przystają do zachodniej kultury. Doraźnym tego efektem jest narastający antysemityzm, długotrwałym zaś - polityczne zwycięstwo dynamicznego islamu. W $2022 \mathrm{r}$. Mohammed Ben-Abbes zostaje prezydentem Francji i zaprowadza w niej stopniowo islamski porządek. Myriam, przyjaciółka głównego bohatera

\footnotetext{
35 É. Zemmour, Le suicide Français, Paris 2014. Zob. też: M. Lilla, The Shipwrecked..., s. $110-116$.

36 M. Houellebecq, Soumission, Paris 2015, wyd. pol.: Ulegtość, Warszawa 2015.
} 
powieści, emigruje do Izraela. M. Houellebecq zgodził się więc z Sarrazinem w kwestii indyferentyzmu elit wobec wartości decydujących o sukcesie Zachodu (dzięki którym stał on się m.in. magnesem dla imigrantów z zewnątrz), ale też ostrzegał, że praktykowanie multikulturalizmu uruchomiło procesy rozpadu, które mogą być nieodwracalne. Oficjalna Francja zareagowała w sposób przewidywalny. Wedle premiera Manuela Vallsa: „Francja to nie Michel Houellebecq ... to nie nietolerancja, nienawiść, strach"37.

Z oskarżeniami o rasizm spotkał się brytyjski neokonserwatywny publicysta, Douglas Murray, który opublikował w 2017 r. podobnie do Uległości katastroficzną w swej ogólnej wymowie książkę pt. Przedziwna śmierć Europy: Imigracja, tożsamość, islam ${ }^{38}$. Zwraca on w niej uwagę szczególnie na dwie kwestie. Po pierwsze, że europejskie elity dawno straciły chęć walki o europejską tożsamość. Co więcej, uważają, że dobrze się stało, że Europa straciła swą kulturową i etniczną homogeniczność, że odrzuciła swoje chrześcijańskie korzenie, na rzecz - rzekomo - samo się uzasadniających „praw człowieka”, że w europejskiej integracji rozmyła państwo narodowe (traktowane przez te elity jako agent zła), które Europa wcześniej stworzyła, żeby gwarantowało porządek konstytucyjny, prawa wolnościowe, a ostatecznie także pokój. Jednocześnie, elity, które afirmują taką ewolucję europejskich wartości i instytucji, uniemożliwiają debatę o rzeczywistości i w związku z tym szukanie rozwiązań ${ }^{39}$. Po drugie, samouzależnienie Europy Zachodniej od imigracji, którego początki datują się do lat sześćdziesiątych i siedemdziesiątych XX w. spowodowało, że dzisiejsza Europa nie ma już wspólnych wartości. Nawet, gdyby chciała do nich wrócić, to nie ma do czego. Nawet, gdyby chciała aktywniej akulturować masy imigrantów, to nie ma jak.

I w takim właśnie momencie, kiedy Europa przestała rozumieć czym jest, świat stawia się u jej drzwi. O ile napływ milionów z obcych kultur do kultury silnej i pewnej swoich wartości mógłby się powieść, napływ milionów do kultury mającej poczucie winy, steranej i zamierającej powieźć się nie może. Nawet jeśli europejscy przywódcy mówią o potrzebie większego nacisku na inkorporację przybyszy ${ }^{40}$.

37 A. Flood, Houellebcq's Soumission becomes an instant bestseller in wake of Paris attacks, «The Guardian» 16.01.2015, https://www.theguardian.com/books/2015/jan/16/michelhouellebecq-soumission-bestseller-charlie-hebdo (12.10.2020).

D. Murray, The Strange Death of Europe: Immigration, Identity, Islam, London 2017.

39 Tamże, s. 1-6.

40 Tamże, s. 7. 
Zdaniem D. Murraya, kiełkować zaczyna w Europie Zachodniej niejasne przeczucie, że w kulturalnie „post-europejskiej” Europie może nie być zbyt wiele tolerancji dla lewicy, feminizmu, aktywistów na rzecz praw mniejszości, szczególnie zaś homoseksualizmu. Ale zasadniczo scenariusze na przyszłość nie rysują się optymistycznie. Europejscy politycy nadal są z siebie zadowoleni. Nie czują się winni kryzysu imigracyjnego. $\mathrm{Z}$ tych powodów, D. Murray przestrzega, że ta polityczna nonszalancja, ignorowanie odczuć ludności rodzimej, obrażanie jej epitetami o zacofanie, rasizm, tylko dla tego, że chce być gospodarzem we własnych krajach, może nie skończyć się dobrze ${ }^{41}$.

Po drugiej stronie Atlantyku, podobną do T. Sarrazina, É. Zemmoura i D. Murraya analizę zaprezentowała popularna konserwatywna komentatorka Ann Coulter w wydanej w 2015 r. książce, pod wymownym tytułem iAdios, America! Tytuł ten wskazuje na wiele, lecz nie mówi wszystkiego. A. Coulter nie obwinia bowiem latynoskich imigrantów za problemy Ameryki. W podtytule wyjaśnia, że chodzi jej o „plan lewicy zamienienia jej kraju w trzecioświatowe badziewie (hellhole)" ${ }^{42}$. Tolerowanie nielegalnej latynoskiej imigracji do Ameryki służy bogatym, szkodzi zaś zwykłym ludziom, w tym legalnym imigrantom. Biznesowi daje tanią siłę roboczą, elitom - tanią służbę. Imigranci nie konkurują z elitami o miejsca pracy, lecz z niżej kwalifikowanymi pracownikami rodzimymi, w tym z wcześniejszymi imigrantami. A. Coulter zauważyła też, że przynoszą oni ze sobą trzecioświatowe wartości i zachowania, które ostatecznie podmywają anglosaską kulturę, z której wyrósł amerykański dobrobyt. I wreszcie, wbrew temu, co twierdzi lewica, nie zwiększają oni wcale kulturowej „różnorodności”, gdyż imigranci do Stanów Zjednoczonych pochodzą głównie z jednego regionu świata - biednych krajów Ameryki Łacińskiej. Diagnozę A. Coulter podziela liberalny komentator, autor ważnej książki o narastających w dobie globalizacji podziałach społecznych, Mickey Kaus ${ }^{43}$. Kaus daje wyraz poparciu tez A. Coulter nt. latynoskiej imigracji do Stanów Zjednoczonych, występując wraz z nią publicznie, np. na prestiżowym Columbia University ${ }^{44}$. Podkreślić należy, że o ile publicystyka M. Kausa próbuje wpływać na sposób myślenia liderów amerykańskich demokratów,

41 Tamże, s. 308-320.

42 A. Coulter, iAdios America! The Left's Plan to Turn Our Country Into a Third World Hellhole, Washington, D.C. 2015.

43 M. Kaus, The End of Equality, New York 1995.

44 Zob. np. Ann Coulter Vs. Mickey Kaus Immigration Debate: 2018 Columbia University, 27.03.2018, https://www.youtube.com/watch?v=NERPl6WF51c (12.10.2020); K. Huangpu, Ann Coulter decries immigration at CUCR-hosted event, «Columbia 
to książka A. Coulter i w ogóle jej poglądy na imigrację ukształtowały myślenie ówczesnego kandydata na prezydenta USA, Donalda Trumpa.

Publikacje tego rodzaju, mimo ataków i ostracyzmu liberalno-lewicowego „głównego nurtu” opinii, coraz bardziej ośmielały „milczącą większość", aż zaczęły przekładać się na polityczne fakty. Ostatecznym z nich okazał się wybór Donalda Trumpa na prezydenta Stanów Zjednoczonych, ale przecież przesunięcie poparcia wyborców na prawo zaznaczyło się już wcześniej także w Europie, gdzie ugrupowania tożsamościowe, takie jak Pegida, Alternative für Deutschland w Niemczech, Front National we Francji, Szwedzcy Demokraci, Duńska Partia Ludowa, Partia Wolnościowa w Austrii, Liga we Włoszech, Vox w Hiszpanii i podobne ugrupowania zyskiwały coraz wyższe poparcie wyborców ${ }^{45}$. Liberalni badacze, jak np. Jonathan Haidt, Arlie Russell Hochchild (a w Polsce, lewicowy Maciej Gdula) zaczęli dociekać motywów odwracania się od lewicy wyborców z warstw mniej zamożnych (jej dotychczas „naturalnej” klienteli) ${ }^{46}$. Być może znaczącą rolę w wyłonieniu się nowego konsensusu aksjologicznego w sprawie imigracji odegra książka liberalnego profesora nauk politycznych Columbia University, Marka Lilli, Ówczesny i przyszty liberał, o tym jak amerykańska lewica tj. Partia Demokratyczna, zdradziła zwykłych Amerykanów, amerykańską klasę średnią, na rzecz „polityki tożsamości”, tj. promowania interesów i praw różnych mniej lub bardziej wymyślonych „mniejszości”. Ta błędna i obłędna polityka, zdaniem M. Lilli, dała w 2016 r. zwycięstwo Donaldowi Trumpowi ${ }^{47}$. Oto kilka charakterystycznych cytatów z książki M. Lilli:

Amerykańska lewica [American liberalism] w XXI w. znalazła się w kryzysie: z naszej strony jest to kryzys wyobraźni i ambicji, ze strony społeczeństwa - kryzys więzi i zaufania. Większość Amerykanów dała nam wyraźnie do zrozumienia, że nie przemawia już do nich nasze przesłanie, które serwowaliśmy im przez ostatnie dziesięciolecia ${ }^{48}$.

Spectator», 28.03.2018, https:/www.columbiaspectator.com/news/2018/03/28/coulterkaus-decry-immigration-at-cucr-event/ (12.10.2020).

45 Europe and right-wing nationalism: A country-by-country guide, «BBC News», 13.11.2019, https://www.bbc.com/news/world-europe-36130006 (12.10.2020).

46 J. Haidt, The Righteous Mind: Why Good People Are Divided by Politics and Religion, New York 2013; A. Russell Hochschild, Strangers in Their Own Land: Anger and Mourning on the American Right, New York 2016; M. Gdula, Dobra zmiana w miastku. Neoautorytaryzm $w$ polskiej polityce z perspektywy małego miasta, Warszawa 2017, https://krytykapolityczna. $\mathrm{pl} /$ instytut/raport-dobra-zmiana-w-miastku/ (12.10.2020).

47 M. Lilla, The Once and Future Liberal: After Identity Politics, New York 2017.

48 Tamże, s. 5. 
(...)

Przed amerykańską lewicą stanęło poważne wyzwanie: stworzyć nową wizję wspólnej przyszłości kraju, odpowiadającą nowej rzeczywistości i oczyszczoną z dotychczasowych błędów. Lewica tu zawiodła. Zamiast tego rzuciła się wspierać politykę ruchów tożsamościowych, tracąc zainteresowanie tym co nas łączy, jako obywateli i jako naród ${ }^{49}$.

(...)

Nie może być lewicowej polityki bez poczucia naszości, wspólnoty (without a sense of we) $)^{50}$.

W Europie podobnie rozwój wypadków analizował Ivan Krastev w książce After Europe ${ }^{51}$. Ogłosił ją - tak jak M. Lilla - w 2017 r. I. Krastev - wybitny ekspert w sprawach europejskich, jest jednocześnie członkiem liberalnego establishmentu, wszak kieruje sofijskim Centre for Liberal Strategies. Jako Bułgar dobrze jednak rozumie postkomunistyczną Europę Środkową; mniej się też chyba krępuje polityczną poprawnością. I. Krastev wprost stwierdza, że kryzys imigracyjny 2015 r. nie tylko ostatecznie zburzył dotychczasowy liberalny konsensus w sprawie imigracji i multikulturalizmu (dokładnie z tych samych powodów, które wskazał M. Lilla pisząc o „zdradzie liberalnych elit” ${ }^{2}$ ), ale że wręcz grozi to dezintegracją Unii Europejskiej; Brexit może być jej tylko pierwszym etapem. Winą za to obarcza samych liberałów ${ }^{53}$. Co więcej, w kwestii przyjmowania imigrantów w 2015 r. stwierdza, że to państwa Europy Środkowej miały powody żeby przeciwstawiać się niemieckiej, i szerzej - zachodnioeuropejskiej, Willkommenskultur. Europa Środkowa boleśnie doświadczyła w swej historii zarówno mulitkulturalizmu - jej przekleństwem była wieloetniczność tamtejszych państw, jak i komunistycznego odgórnie narzucanego kosmopolityzmu. Dlatego ceni się tam spójność narodową i kulturową widząc w nich istotny czynnik pokoju społecznego oraz współpracy międzynarodowej. Społeczeństwa bałkańskie, czeskie, słowackie i węgierskie, zmagają się też z nierozwiązywalnym problemem integracji Cyganów. Wiedzą więc dobrze, że istnieją takie grupy etniczne, których nie da się w Europie zintegrować ${ }^{54}$. Krytyczny stosunek do Willkommenskultur szybko rozszerzył się z Europy Środkowej na Europę Zachodnią. Niemcy, których wielu w 2015 r. witało arabskich i afrykań-

49 Tamże, s. 8-9.

50 Tamże, s. 14.

51 I. Krastev, After Europe, Philadelphia 2017.

52 Tamże, s. 86-93.

53 Tamże, s. 2-3, 13-14, 19, 25-26, 31-35, 38.

54 Tamże, s. 38-59. 
skich imigrantów, dziś mają już inne podejście. Nie da się więc Europy Środkowej w tej kwestii politycznie izolować oraz potępić. Podejmowanie takich prób może doprowadzić do dezintegracji UE. Ludzie nie lubią tracić kontroli nad losem swoim i swoich krajów. A do takiego właśnie stanu świadomości doprowadziła obywateli UE dotychczasowa polityka. Dlatego zmiana polityki imigracyjnej UE nie może być tylko kosmetyczna, musi być zasadnicza. UE musi odzyskać kontrolę nad swymi zewnętrznymi granicami, zaś poszczególne państwa członkowskie nad swoim losem. Rozpuszczanie ich w wielokulturowej magmie to recepta na katastrofę. „Uelastycznienie - nie usztywnienie - oto co może jeszcze uratować Europę" 55 .

Symboliczną niejako klamrę spinającą ten etap rewizji dotychczasowego konsensusu imigracyjnego stanowi książka Francisa Fukuyamy o znaczeniu tożsamości, wydana w 2018 r., tj. 29 lat po proklamowaniu przez niego „końca historii”, co tak wówczas rozsierdziło Samuela Huntingtona ${ }^{56}$. Jak skwitował Louis Menand, F. Fukuyama „odłożył koniec historii na później” 57 . Tak jak kiedyś uniwersalizacja liberalnej demokracji miała być panaceum na konflikty wartości, tak teraz głównym zagrożeniem globalnego porządku liberalnego jest platoński thymos (gr. $\theta v \mu o ́ \varsigma$ ), tj. ten aspekt natury ludzkiej, który domaga się uznania. Obok rządzy i rozumu, thymos jest częścią składową ludzkiej duszy. Ignorowanie tej uniwersalnej potrzeby prowadzi m.in. do Brexitu, odrodzenia nacjonalizmu, sprzeciwu wobec imigracji oraz oddania władzy takim politykom jak Donald Trump, Jarosław Kaczyński, czy Viktor Orbán, którzy uosabiają - zagrożone przez rozmaite przejawy globalizacji - wartości takie jak narodowa tożsamość i suwerenność58. Przy czym, lewica też „celebruje” tożsamość, tyle że już nie „klasy pracującej” czy „ekonomicznie wyzyskiwanej”, lecz grup społecznych, które uznaje za ofiary większości, dlatego w demokracji politycznie przegrywa ${ }^{59}$. I będzie przegrywać, gdyż - jak dowodzi F. Fukuyama - thymos jest zakorzeniony w biologicznych strukturach i procesach ludzkiego mózgu ${ }^{60}$. Społeczeństwa zdominowane

55 Tamże, s. 58, 71-81, 110 (cyt. s. 110).

56 F. Fukuyama, Identity: Contemporary Identity Politics and the Struggle for Recognition, London 2018.

57 L. Menand, Francis Fukuyama Postpones the End of History, «The New Yorker» August 27, 2018.

58 F. Fukuyama, Identity..., s. 12-24, 74-90. Podobnie, M. Lilla, The Shipwrecked..., s. 107-108.

59 F. Fukuyama, Identity..., s. 90.

60 Tamże, s. 15. 
przez politykę grupowych tożsamości, a więc pozbawione wspólnoty wartości, nie mogą organizować się do współpracy, gdyż brak im instytucji, których prawomocność nie byłaby kwestionowana. To z kolei rodzi niepokój i chęć zwierania szeregów; następuję ucieczka od liberalnej demokracji ${ }^{61}$. Uratować ją może powrót do uniwersalizacji wartości w ramach narodowej wspólnoty. Dlatego, tak jak to trafnie zauważyła Dominika Kozłowska, F. Fukuyama postuluje energiczniejsze działania na rzecz kulturowej integracji imigrantów ${ }^{62}$. Odnotować też trzeba polityczną ewolucję samego F. Fukuyamy, który w 1989 r., zapowiadając „koniec historii”, zaczynał jako republikański neokonserwatysta, dziś zaś kończy, jako propagujący kulturową asymilację imigrantów demokrata ${ }^{63}$.

\section{Zakończenie}

Zanim jeszcze w 2015 r. podczas kryzysu migracyjnego Victor Orbàn, Jarosław Kaczyński oraz inni liderzy Europy Środkowej i Bałkanów zbuntowali się przeciwko próbom narzucania ich krajom polityki pobłażliwości wobec napływu imigrantów (V. Orbán nie zawahał się nazwać tych prób „imperializmem kulturowym”64), czołowi przywódcy Zachodu Europy zaczęli zmieniać retorykę. Już w październiku 2010 r. Angela Merkel publicznie oświadczyła, że multikulturalizm w stosunku do imigrantów „zawiódł, zawiódł na całej linii”65. Kilka miesięcy później premier Wielkiej Brytanii David Cameron wyjaśnił przyczyny tej klęski: „Zgodnie z oficjalnie przyjętą doktryną multikulturalizmu, zachęcaliśmy różne kultury do życia we wzajemnej separacji oraz w oderwaniu od głównego nurtu. Nie zdołaliśmy zaproponować im wizji społeczeństwa, którą zechciałyby z nami podzielać. Przyzwalaliśmy nawet na to, by społeczności te funkcjonowały w sposób zupełnie sprzeczny z naszymi warto-

61 Tamże, s. 55-56.

62 Tamże, s. 163-183.

63 F. Fukuyama, After Neoconservatism, «The New York Times» 19.022006, https://www. nytimes.com/2006/02/19/magazine/after-neoconservatism.html (12.10.2020).

64 N. Werkhäuser, Hungary's Orban criticizes Merkel's „moral imperialism”, «Deutsche Welle» 23.09.2015, https://www.dw.com/en/hungarys-orban-criticizes-merkels-moralimperialism/a-18736240 (12.10.2020).

65 S. Siebold, Merkel says German multiculturalism has failed, «Reuters» 16.10.2010, http:// www.reuters.com/article/idUSTRE69F1K320101016 (12.10.2020). Podobnie Merkel wypowiedziała się w 2015 r.: R. Noack, Multiculturalism is a sham, says Angela Merkel, «The Washington Post»14.12.2015, https://www.washingtonpost.com/news/worldviews/wp/2015/12/14/angela-merkel-multiculturalism-is-a-sham/ (12.10.2020). 
ściami”66. W podobnym duchu wypowiadali się też wówczas prezydent Francji Nicolas Sarkozy oraz premier Hiszpanii José María Aznar67. Czzy deklaracje te wynikały tylko ze strachu przed wyborcami przerażonymi terroryzmem oraz kulturowym autoapartheidem europejskich metropolii, czy tė̇ odzwierciedlały wyłanianie się nowego konsensusu elit głównego nurtu wobec imigracji? Kryzys imigracyjny roku 2015 nie dał na to jasnej odpowiedzi.

\section{Bibliografia}

Ari E., Ideology of Multiculturalism as a Double-Edged Sword: Second-Generation of Black Jamaicans and Dark-White Portuguese, https://ir.lib.uwo.ca/etd/5353 (12/10/2020).

Bickerton C., The collapse of Europe's mainstream left, «New Statesman» 1.05.2018, https:// www.newstatesman.com/world/europe/2018/05/collapse-europe-s-mainstream-centreleft (12.10.2020).

Bock-Côté M., Le multiculturalisme comme religion politique, Paris 2016), wyd. pol.: Multikulturalizm jako religia polityczna, Warszawa 2017.

Bloom A., The Closing of the American Mind: How Higher Education Has Failed Democracy And Impoverished the Souls of Today's Students, New York 1987.

Caputo J., The Prayers and Tears of Jacques Derrida: Religion Without Religion, Bloomington 1997.

Coulter A., iAdios America! The Left's Plan to Turn Our Country Into a Third World Hellhole, Washington, D.C. 2015.

Derrida J., Structure, Sign and Play in the Discourse of Human Sciences, http://www2.csudh. edu/ccauthen/576f13/DrrdaSSP.pdf (8.10.2020).

Derrida J., White Mythology: Metaphor in the Text of Philosophy, [w:] Derrida J., Margins of Philosophy, Chicago 1984.

Fallaci O., La rabbia e l'Orgoglio, Milano 2001, wyd. pol. Wściektość i duma, Warszawa 2003.

Fukuyama F., The End of History?, «The National Interest», Summer 1989, nr 16.

Fukuyama F., Identity: Contemporary Identity Politics and the Struggle for Recognition, London 2018.

Fukuyama F., After Neoconservatism, «The New York Times», 19.022006, https://www.nytimes.com/2006/02/19/magazine/after-neoconservatism.html (12.10.2020).

Gdula M., Dobra zmiana $w$ miastku. Neoautorytaryzm $w$ polskiej polityce $z$ perspektywy matego miasta, Warszawa 2017, https://krytykapolityczna.pl/instytut/raport-dobra-zmiana-wmiastku/ (12.10.2020).

66 D. Cameron, PM's speech at Munich Security Conference, 5.02.2011, https://www.gov.uk/ government/speeches/pms-speech-at-munich-security-conference (10.10.2020).

67 Sarkozy declares multiculturalism 'a failure', «France 24», 10.02.2010, https://www. france24.com/en/20110210-multiculturalism-failed-immigration-sarkozy-live-broadcasttf1-france-public-questions https://www.france24.com/en/20110210-multiculturalismfailed-immigration-sarkozy-live-broadcast-tf1-france-public-questions $(10.10 .2020)$. 
Gjelten T., The Immigration Act That Inadvertently Changed America, «The Atlantic», 2.10.2015, https://www.theatlantic.com/politics/archive/2015/10/immigration-act-1965/408409/ $(12.10 .2020)$.

Haidt J., The Righteous Mind: Why Good People Are Divided by Politics and Religion, New York 2013.

Hicks S., Explaining Postmodernism: Skepticism and Socialism from Rousseau to Foucault, b.m.publ. 2011.

Houellebecq M., Soumission, Paris 2015, wyd. pol. Ulegtość, Warszawa 2015.

Huangpu K., Ann Coulter decries immigration at CUCR-hosted event, «Columbia Spectator» 28.03.2018, https://www.columbiaspectator.com/news/2018/03/28/coulter-kaus-decryimmigration-at-cucr-event/ (12.10.2020).

Huntington S., The Clash of Civilizations?, «Foreign Affairs», 1994, vol. 72, nr 3.

Huntington S., Who Are We? America's Great Debate, London 2004.

Judt T., Ill Fares the Land, New York 2010.

Kaus M., The End of Equality, New York 1995.

Koppel T., Truth be Told: Journalism in the Age of Trump, «The Kalb Report», Washington, D.C. 2018, https://www.youtube.com/watch?v=DzQZsudzLao (12.10.2020).

Krastev I., After Europe, Philadelphia 2017.

Laqueur W., The Last Days of Europe: Epitaph for an Old Continent, New York 2007.

Lilla M., The Once and Future Liberal: After Identity Politics, New York 2017.

Lilla M., The Shipwrecked Mind: On Political Reaction, New York 2016.

Malik K., The Failure of Multiculturalism: Community Versus Society in Europe, «Foreign Affairs», 2015, vol. 94, nr. 2, s. 21.

Murray D., The Strange Death of Europe: Immigration, Identity, Islam, London 2017.

Rector R., Look to Milton: Open borders and the welfare state, The Heritage Foundation, 21.06.2007, https://www.heritage.org/immigration/commentary/look-milton-open-borders-and-the-welfare-state $(12.10 .2020)$.

Russell Hochschild, A., Strangers in Their Own Land: Anger and Mourning on the American Right, New York 2016.

Sarrazin T., Deutschland schafft sich ab: Wie wir unser Land aufs Spiel setzen, München, 2010. Zemmour É., Le suicide Français, Paris 2014. 